\title{
Medieval Mortars and the Gothic Revival: The Cosmati Pavement at Westminster Abbey
}

\author{
Ruth Siddall \\ UCL Earth Sciences, Gower Street, London,WC1E 6BT, UK., r.siddall@ucl.ac.uk
}

\begin{abstract}
In the 1870s the architect Sir George Gilbert Scott was appointed Surveyor to the Fabric at Westminster Abbey and one of his major initiatives was to restore the Cosmati Pavement in the Sanctuary. Originally commissioned by Henry III in the late $14^{\text {th }}$ Century, this luxury pavement employed the Cosmatesque technique with materials and possibly artisans imported from Rome. As such, this pavement is the only remaining example if this type north of the Alps, and is one of the very few examples which retains much of its original mortars. These original mortars were developed to cope with the damp conditions of the Thames riverbank and are hydraulic limes which use crushed terracotta as a pozzolana. During the restoration in the $1870 \mathrm{~s}$, Gilbert-Scott attempted to replicate the appearance of these materials whilst using contemporary Portland cement mixes with a series of special additives. This paper presents a textural and petrological study, using optical polarising light microscopy, and compares the compositions and manufacturing technologies of the original $14^{\text {th }}$ Century mortars with those of the $19^{\text {th }}$ Century restorations.
\end{abstract}

Keywords: Cosmatesque, cocciopesto, Westminster Abbey, Portland Cement.

\section{Introduction}

Situated in front of the High Altar of Westminster Abbey, the Sanctuary Pavement is the centrepiece of both the current church and that of the Pavement's patron, Henry III. It is constructed in the Cosmatesque style, depicting nine roundels arranged in two superimposed quincunxes and surrounded by a further 20 roundels making up the border of the floor. These are interspersed with rectangular tomb covers at the north, south, east and west sides of the floor. However, the early date of construction of this floor, probably 1268-69, and subsequent survival with only small patches of restoration, makes it an unique piece of architectural stonework. The Cosmatesque style is a form of opus sectile decorative stonework, where different shaped pieces of coloured stones are arranged, rather like a patchwork quilt within a framework, usually of marble, but in this case Purbeck Stone. The coloured stones are predominantly Roman spolia, typically green lapis lacedaemonius porphyry from Krokeai near Sparta and the purple porphyry of Mons Claudianus in the Egyptian Eastern Desert.

The floor was commissioned by Henry III as part of his reconstruction of Westminster Abbey arranged to coincide with the translation of the tomb of Edward the Confessor on $13^{\text {th }}$ October 1269 and was probably finished at around this time or slightly later (Carpenter, 2002; Binski 2002). The Confessor's shrine and the pavement surrounding this, as well as Henry III's tomb are also decorated in the Cosmatesque style and some aspects of this work necessarily post-date the floor (Binski, 2002).

There are four main phases of construction or repair in the $13^{\text {th }}, 17^{\text {th }}, 18^{\text {th }}$ and $19^{\text {th }}$ Centuries, known respectively as the Primary, Secondary, Tertiary Mixes and Scott Repairs as defined by Foster (2002) and summarised by Durnan (2002). This paper will concentrate on the Primary Mix and the Scott Repair.

The Westminster Abbey Sanctuary pavement is arguably unique. It is the only surviving floor of its type north of the Alps, and evidence presented here suggests that it is potentially one of a kind; the large number of $12^{\text {th }}$ and $13^{\text {th }}$ Century Cosmati and Cosmatesque floors in Italy have been re-laid and few retain any evidence of their original mortars. Pajares-Ayuela (2001) has provided a comprehensive review of 
Cosmati and Cosmatesque work in terms of their precedents, designs, geometries and art historical significance. Foster (1991) similarly provides a comprehensive discussion of the Westminster Abbey pavement.

\section{Methodology and analytical details}

The floor was surveyed macroscopically, using as a base map the digitised plan of the Sanctuary Pavement produced by N. Durnan \& The Downland Partnership (1997). Each section of inlaid Cosmatesque work with the same mortar characteristics was assigned a number and the materials, including the stones used, were described macroscopically. In this way, 145 separate areas were identified on the pavement. These are shown on the annotated copy of the map in Figure 1. Macroscopic examination of the mortars allowed them to be grouped into main types based on their colour and visible inclusions. These corresponded well with the main identified phases of construction and restoration. Samples were collected from lose fragments when possible (Table 1). Otherwise they were removed using a hammer and chisel or a mechanical cutting instrument. The most useful method of analysing the mortar and aggregate composition is to use the standard method employed for the petrographic analysis of geological and ceramic materials, to make a thin section of the material, mounted on a glass microscope slide which may then be analysed using polarised light microscopy (PLM; St John et al., 1998). A sample needs to be larger than $10 \mathrm{~mm}^{3}$ for effective use of this technique. Due to the very small fractions of mortar available for sampling in many cases, it was impossible to do this for all samples. From the remainder a sub-sample was taken which was pulverised to make a grain mount in MeltMount ${ }^{\mathrm{TM}}(\mathrm{RI}=1.662)$ for analysis using PLM. Samples were also prepared as stubs for analysis using scanning electron microscopy.

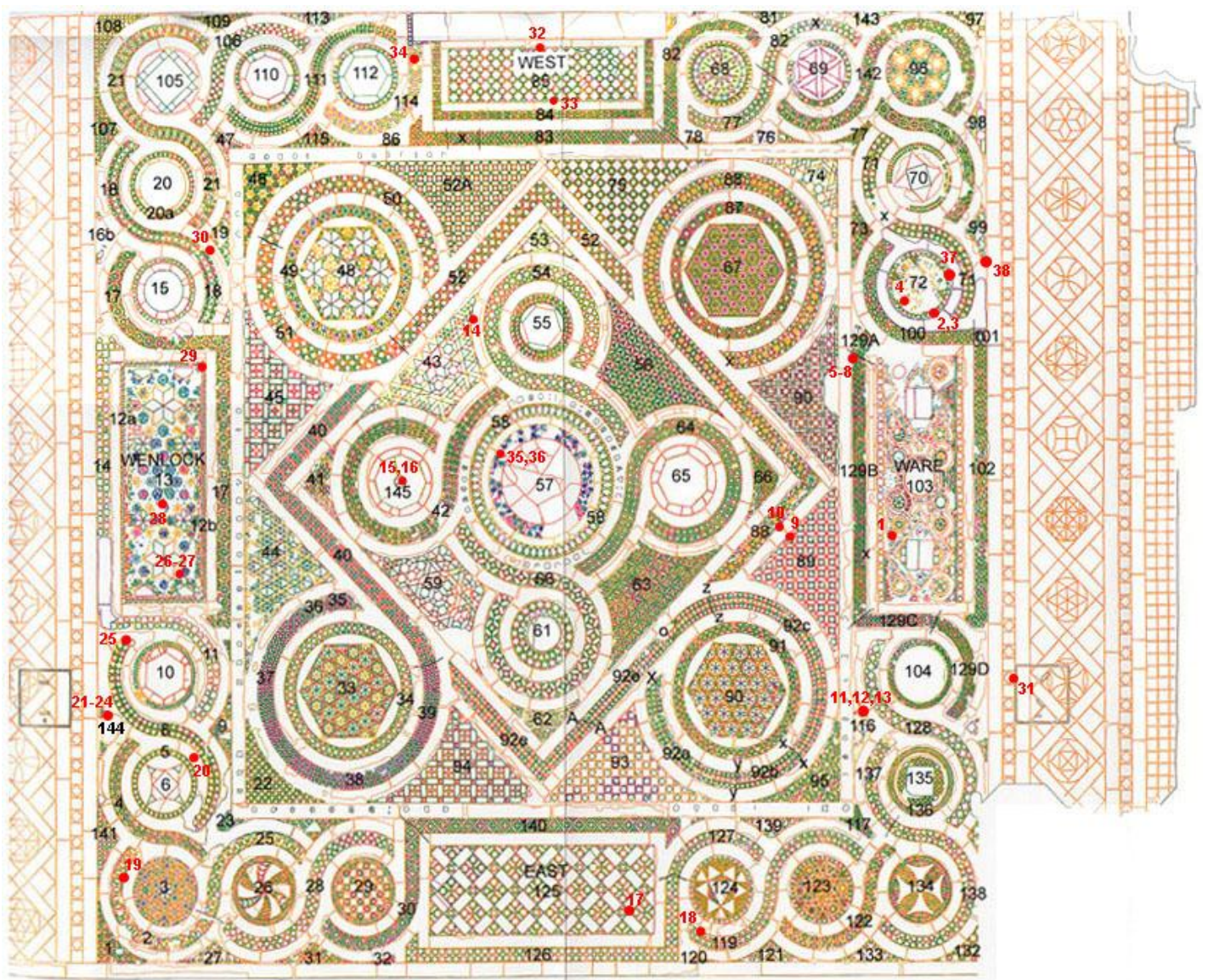

Fig. 1. Plan of the Sanctuary Pavement showing the numbering of the sectors (black) used in this report and the locations of mortar samples collected (red). Adapted from N. Durnan \& The Downland Partnership (1997). 
Optical analysis of the materials was carried out on a Leitz Orthoplan-Pol microscope with a maximum optimum magnification of $1000 \mathrm{x}$. Photomicrographs were taken with a Nikon Coolpix digital camera. Observations were made in both plane-polarised light (PPL) and under crossed polars (XPL). The aggregate clasts, and to a certain extent, the fine grained cement paste, may be readily identified using techniques routinely used by geologists and described in texts including Deer et al., (1992), Tucker (1991) and Adams et al., (1991). In addition as man-made ceramic materials, terminology developed for the description of archaeological ceramics is also useful (Whitbread, 1986, 1989 and Freestone, 1995). Portland cements are entirely man-made materials and the phases present are not encountered occurring in nature.

A selection of samples were additionally analysed using scanning electron microscopy coupled with an Energy Dispersive System (SEM-EDS), carried out on a JEOL JSM-6480LV high-performance, variable pressure analytical SEM in UCL Earth Sciences. Scanning electron microscopy is a useful technique for examining the typically very finely crystalline cement pastes and when coupled with EDS analysis this technique can also provide a good determination of chemical composition. Stubs of paste were coated with carbon for EDS analysis and with gold for higher resolution SEM imaging. Samples analysed were small, with dimensions of $2-3 \mathrm{~mm}$.

\section{The Primary Mix mortars}

The Primary Mix mortars and stones were laid c. 1268 (Foster, 2002). Over three quarters of the sectors analysed revealed evidence of either the original construction of the floor or very early repairs. These areas are distinctive in the use of cocciopesto mortars which are weakly hydraulic due to the use of crushed and ground ceramics as a pozzolanic additive.

\begin{tabular}{ccc}
\hline Sample Number & Location Sector & Phase \\
\hline 1 & 103 Ware's Tomb & Primary Mix \\
3 & 72, North Border & Primary Mix \\
10 & 88, outer quincunx & Primary Mix \\
15 & 145, inner quincunx & Primary Mix \\
16 & 145, inner quincunx & Primary Mix \\
17 & 125, East Tomb & Scott's Repair \\
18 & 119, South Border & Scott's Repair \\
19 & 2, South Border & Primary Mix \\
25 & 8, South Border & Primary Mix \\
28 & 13, Wenlock's Tomb & Primary Mix \\
30 & 18, South Border & Scott's Repair \\
31 & Pavement Border & Scott's Repair \\
33 & 85, West Tomb & Scott's Repair \\
34 & 57, Central Roundel & Primary Mix \\
35 & 57, Central Roundel & Primary Mix \\
38 & 72, North Border & Scott's Repair \\
\hline
\end{tabular}

Table 1: Sample locations and phases.

The most striking aspect of this earliest phase of the mortars is that they were clearly intended to form an integral part of the design. The decorative stones are not closely fitted and each is surrounded by mortar, leaving several millimetres (between 2-10 mm) of mortar-filled spacing between each stone. Macroscopic examination of these mortars showed them to be distinctive, with cement pastes ranging in colour from deep red-orange to a pale ivory. The aggregate is formed from a pozzolanic additive of crushed and powdered ceramics plus a geological material with particles of variable composition (Fig. 2). The colour is due to powdered ceramic sherds and colour intensity shows considerable variation across the floor. The surface has yellowed over time, and in places where the setting mortar is revealed (under the central roundel of sector 145 and 144) it is shown to be varying shades of pink. Aggregate is batched to the cement at ratios of $\sim 2: 1$. In some cases, it would appear that an upper, $\sim 2-3 \mathrm{~mm}$ thick layer of grout has come away, leaving a (usually) coarser and paler-coloured setting mortar below. By analogy with other sections of the floor, it would seem that there is an upper grout layer which is richer in 
powdered ceramic than the setting mortars and therefore more hydraulic. However, this 'layer' is not found universally across the Primary Mix areas of the floor.

When viewed under the microscope, the cement paste is optically very active under crossed polars which indicates that it is well carbonated. However, the lime matrix is weakly hydraulic and this property is imparted by the presence of powdered terracotta sherds mixed in with the cement paste. Consequently there are patches visible where this reaction has been more extreme and these areas show lower birefringence. Individual phases within the cement matrix are beyond the resolution of the optical microscope. Also present are unreacted lime and rare particles of partially or unburned limestone. The latter are identified as particles of chalk based on their mineralogical textures and the presence of microfossils.

The aggregate is of two main fractions. Firstly, a sand of geological origin composed of well-rounded grains of single-crystal quartz, a few grains of polycrystalline quartz, glauconite and flint. Grains of carbonate rocks (chalk) are also present. The sand is coarse, with particle size ranging from $\sim 0.2-3 \mathrm{~mm}$. By contrast, the second fraction of the aggregate, though of a similar size range, is composed of very angular fragments of ceramic tile or pot sherds. These particles predominantly have a red clay matrix, with low optical activity with inclusions of quartz and muscovite in varying proportions. A few ceramic particles have black, isotropic clay matrices which may indicate that they are derived from different wares or they may represent blackened cores of otherwise oxidised fabrics. A very fine grained fraction possibly existed, but this would have been consumed by hydraulic reactions. Three distinct ceramic fabrics were identified to be present a black-bodied quartz ware, a red-bodied quartz ware and a red-bodied quartzmuscovite ware.

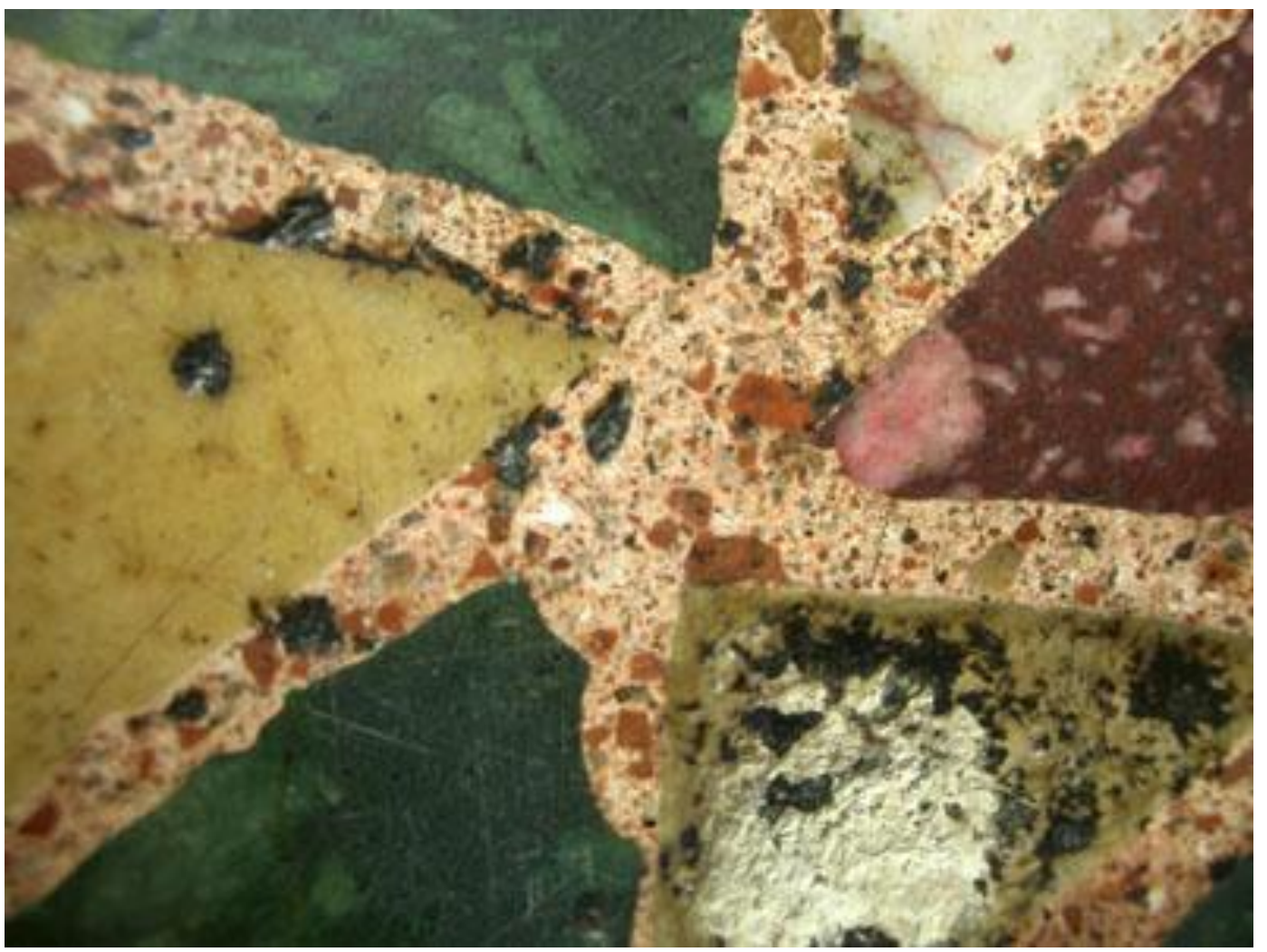

Fig.2. Primary Mix mortars in sector 9, showing the typical pale pink cement paste with a poorly sorted aggregate of orange ceramics and lithic fragments. Field of view is approximately $10 \mathrm{~cm}$ wide.

SEM images showed the mortars to have a $1 \mu \mathrm{m}$ particle size and grains had a subhedral to anhedral morphology with aggregates of platy and rhombic grains present. SEM-EDS analysis of sample 19 showed the chemical composition to be calcium, carbonate and minor silica. Sample 35 also contained traces of alumina and sulphate. 


\section{George Gilbert Scott's Restoration: Main Floor}

Sir George Gilbert Scott was responsible for the layout of the Sanctuary Pavement and the High Altar as we see them today. His restorations took place around 1867-89. Scott has taken considerable care to replicate the mortars used in the Primary Mix showing that he was quite capable of differentiating the various phases of restoration on the Pavement.

The roundels and tomb along the east border of the floor are replacements by Scott, who may have redesigned these sections completely (Foster, 2002). The mortars employed on the Sanctuary Pavement employed by Scott are superficially very similar to those of the Primary Mix, though the lack the strong orange-pink colouration of some of these mortars. The cement paste matrix is cream to ivory in colour and is set flush with the top surface of the stones. It contains an aggregate, clearly visible to the naked eye, of lithic grains and red or orange fragments. These are well sorted, all particles are of a similar size, $\sim 0.5 \mathrm{~mm}$.

Samples 17, 18 and 30 were collected from the east border of the floor and were therefore securely dated to Scott's restoration. In addition, Samples 32 and 33 from the West Tomb were also identified, based on petrographic analysis described here to belong to Scott's phase of restoration. The small fraction of Scott's mortars meant that samples would necessarily be very small. In fact, none were large enough to make a useful thin section, and all were prepared as grain mounts. All samples showed very similar compositional variation.

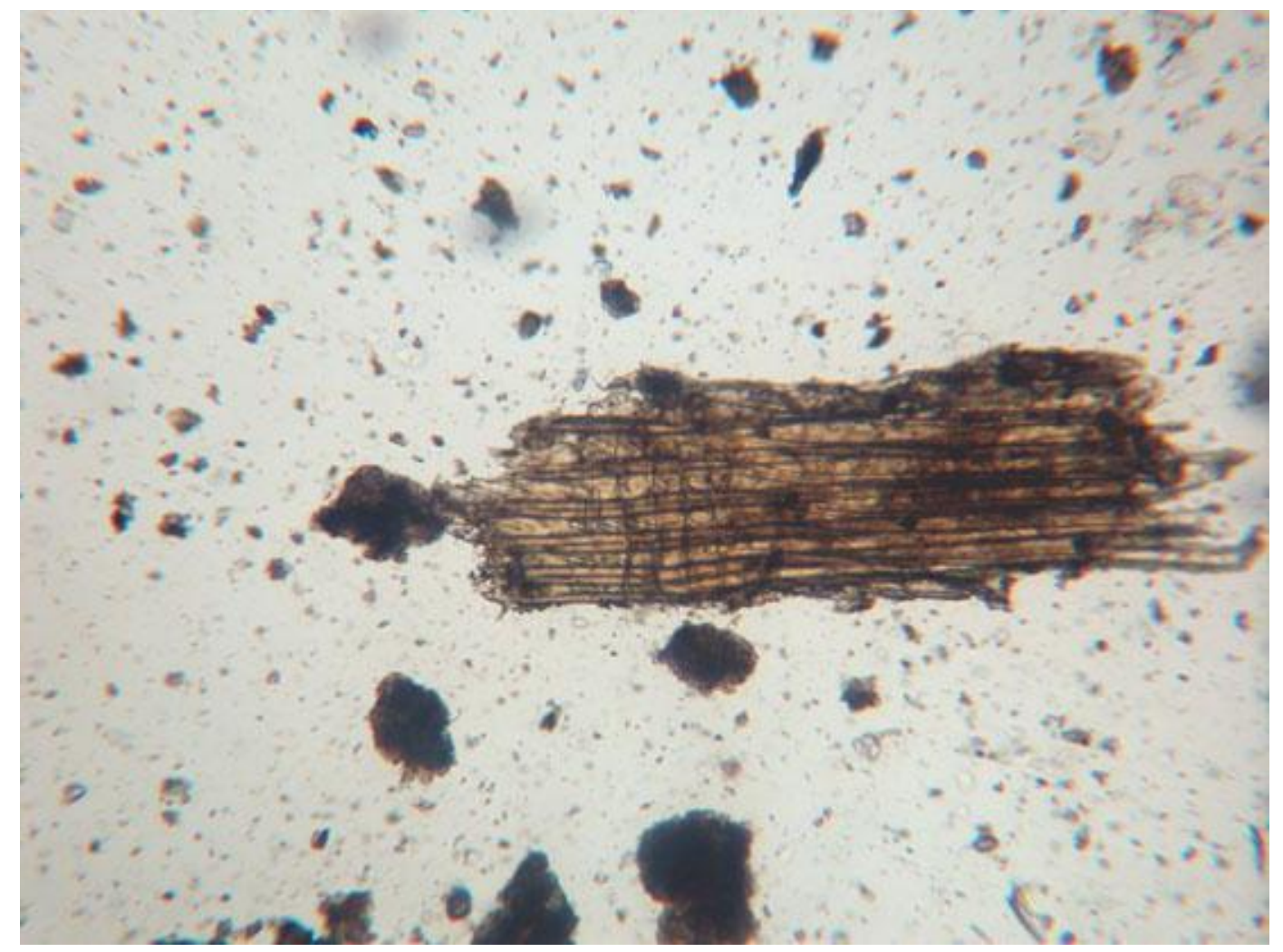

Fig. 3. Vegetable fibres in the grain mount of Sample 32. x 60, plane-polarised light.

The fine fraction (i.e. $<40 \mu \mathrm{m}$ ) observed on the grain mounts were calcium carbonate and a small amount of gypsum; the latter was present in distinctive lath-shaped crystals. Clumps of carbonate plaster, showing characteristic high birefringence were common. Grains of mineral aggregate are fine, subrounded, quartz and flint sand. Red-coloured ceramics are also present, but further identification of these is difficult using the grain mount technique. However, they were shown to be finely polycrystalline and interpreted to be made from iron-rich clays. Additionally present as an additive, and arguably diagnostic of these mortars, were particles of chopped plant bast fibres, which were yellowish in colour when 
observed under PPL. Under crossed polars, these fibres showed second order birefringence colours and inclined extinction (fig. 3).

\section{Scott's Mortars from the North and South Borders}

The borders which flank the north and south edges of the pavement were designed by Sir George Gilbert Scott and laid by his contractors, Poole \& Sons, in 1870 (Foster, 1991, 2002; Jordan, 1980). The borders are composed entirely of Purbeck Stone, grouted with cement. The design features roundels and diagonally-laid sections which clearly echo the design of the floor. Mortars are used to set and point the Purbeck Stone slabs used in the borders. They are brownish-orange in colour and aggregate is not clearly visible to the naked eye.

Two samples were collected from the floor, one was of sufficient size to make a large thin section (Sample 38) but the second was small and a fraction of it was therefore pulverised to make a grain mount (Sample 31).

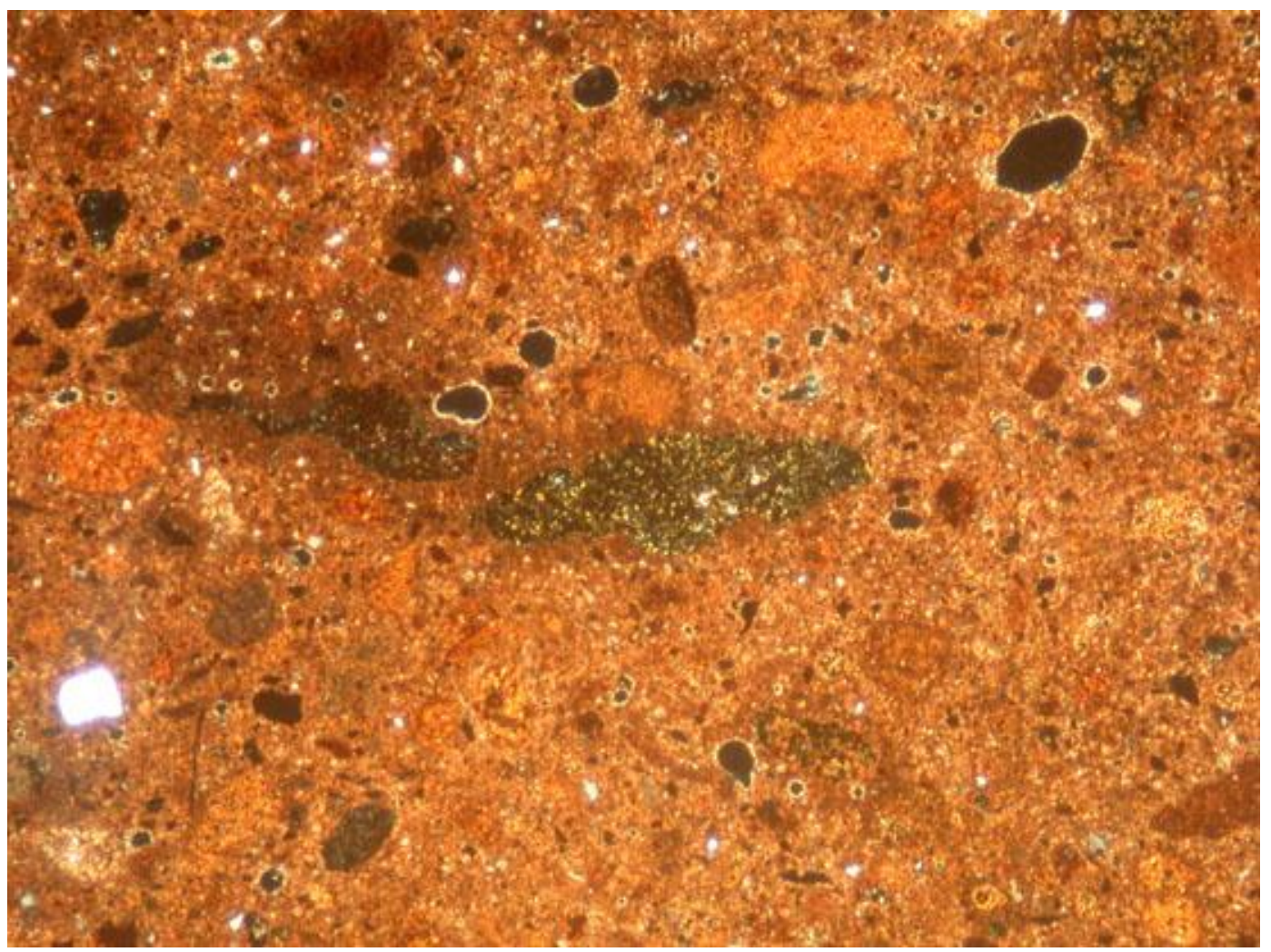

Fig. 4. Sample 38. The field of view above, under crossed polars. Black patches are voids, the darker particle in the centre is blast furnace slag, with a large amount of glass present.

Sample 38 when viewed in PPL has an overall orange colour (Fig. 4). The cement paste is fine grained and mottled and this is particularly evident under crossed polars. In XPL it has high optical activity, and there is clearly a large amount of carbonate present. There is little evidence of unreacted Portland cement clinker kernels being present. Small patches which appear to be colourless, reveal meshes of needle-like crystals of ettringite at higher magnifications (x 400). Areas of fine glass and/or tobermoreite gels are present. The orange colour is promoted by ferrite phases.

Aggregate is a fine quartz sand, and what appear to be crushed ceramics. However they have reacted well with the cement paste and now appear fuzzy and diffuse with blurred, low contrast boundaries between them and the cement paste. Also present are particles of slag containing a wide variety of phases and glasses. Larger particles show a decussate textured slag formed of elongate yellow crystals and interstitial brown crystals and glass. These are interpreted to be blast furnace slags containing melilite and 
associated phases. There is $\sim 20 \%$ porosity in rounded to irregular voids. These are lined with a thin layer of portlandite and secondary calcium carbonate.

The grain mount of sample 31 showed a strong compositional similarity to the thin section of sample 38. The cement paste had a dark colouration in PPL and a range of birefringence colours in XPL. This is composed of glass and/or gel, carbonate, portlandite and possibly ettringite. Lath-shaped crystals showing first order grey birefringence are interpreted to be derived from slags used as an aggregate. Crumb-like aggregates of cement paste were identified and these were moderately well carbonated. Fragments of orange-coloured, particles were interpreted as reacted terracotta. Many particles were yellow in plane polarised light and some small aggregates of yellow and dark, red-brown grains were present. These are probably particles of metal-processing slag. A small amount of quartz is also present as aggregate.

\section{Discussion}

The Primary mix mortars were made using ancient hydraulic lime manufacturing techniques which were originally developed in the $2^{\text {nd }}$ Century $\mathrm{AD}$, for making hardwearing and waterproof floors. This involved mixing the slaked lime with crushed and powdered ceramic material. The Roman name for this material was opus signinum, but it was later called cocciopesto in Italy and this is an appropriate term to describe the mortars of the Sanctuary pavement. These materials were probably calcined using a flare kiln, although there is some evidence of underburning which enables the probably identification of the limestone charge as being the upper Cretaceous Chalk Formation. This may well support a continuation in thinking from the $1^{\text {st }}$ Century AD to the $13^{\text {th }}$ Century that the 'whitest' limestones made the best limes, as put forward by Vitruvius and Cato.

Particles of unreacted lime indicates an incomplete slaking process, whereby the lime was hydrated but contemporaneous with the addition of water, or soon after, it was mixed with the aggregate, before the lime had completely reacted to form portlandite. This shows that the 'hot-mix' technique, whereby the aggregate was added to the lime at the time of slaking and the mortar was used soon afterwards, rather than allowing a long time period for the lime to become completely slaked.

The chemical composition of the mortars, as assessed from EDS analysis of samples 19 and 35 showed them to be composed of calcium carbonate with minor amounts of silicate and sulphate present. This strongly suggests the presence of cement phase associated with hydraulic sets such as calcium silicates and/or calcium silicate hydrates and sulphates. However, actual phases may not be conclusively identified due to the low count totals obtained from the samples. They were probably formed from a mixture of lime and the ceramic pozzolana, with possibly a small fraction of gypsum added. The ceramic sherds are terracottas (i.e. fired at temperatures $<1000^{\circ} \mathrm{C}$ ) and at least 3 different fabrics are identifiable amongst these, suggesting that a variety of waste ceramics were recycled as pozzolanic additives.

The geologically derived aggregates are Thames river gravels which were sourcing the Upper Cretaceous strata of the Thames Basin, the Upper Greensands (indicated by the presence of glauconite) and flints, derived from the Chalk. The relatively restricted grain size of the aggregate and the absence of a very fine fraction suggests that the materials was washed and sieved prior to incorporation with the cement paste.

The variation in colour within the mortars demonstrates that they were mixed in small batches as and when needed. The presence of larger quantities of powdered lime in the upper surface of the pointing mortars may well be as a result of the recently applied mortar being sprinkled with extra ground sherds to further enhance the hydraulic set of the uppermost layer. These regions possibly represent working shifts, whereby a section of foundation mortars was laid, the stones were arranged upon this, allowing for small changes and adjustments of the pattern, and then they were set in place by the pointing mortars. There is only one example of a section where areas of pattern were laid as prefabricated sections. It is possible that these areas represent early repairs to the floor.

Scott's mortars used on the Cosmatesque Pavement are traditional lime mortars, gauged with a small fraction of gypsum mortar. They contain an aggregate of quartz and flint sand and also contain chopped plant fibre. The mineral aggregate is well sorted indicating that it was graded. These materials are in contrast to the Primary Mix mortars which are very poorly sorted, showing aggregate particles of varying size. The presence of the plant fibre was also of note. This component was observed in all samples and was not found in Primary Mix samples, making it a diagnostic indicator of Scott's recipes. Consequently, evidence is presented here that the West Tomb was also re-laid by Scott, though largely using only original stones. It cannot be discounted that other small areas of Primary Mix stones and mortars were repointed by Scott, but no clear evidence for this was noted macroscopically. 
Samples 31 and 38 belongs to Scott's restorations or later. It is feasible to relate it to Scott's construction of the border (1870) based on the similarity of the materials observed macroscopically here. The materials are more obviously hydraulic than the lime-ceramic mortars described previously. They bare some similarities to Portland cements, but with much more calcium carbonate present than would be expected in modern OPC. Scott (or in fact his contractors, Poole \& Sons) have apparently added potsherds to try and match this material with the primary mix, however the sherds have reacted far more strongly and have almost been consumed by the reaction. They have promoted a strong orange colour to the materials. Quartz sand, and slag are also present. Blast furnace slag produces a strong pozzolanic reaction and was frequently used as an aggregate.

It is likely that Scott was experimenting here to produce a cement which resembled the Primary Mix mortars, but for a cheaper, harder wearing and damp resistant material to secure the Purbeck Stone of the borders. He possibly made these with a mixture of lime with very finely ground ceramics and other pozzolanas. Portland Cement clinker was not obviously present in the samples; an hydraulic set may have been promoted by the mixture of finely ground pozzolanas with well slaked limes. The mixture was also probably gauged with gypsum (now reacted to form ettringite?) to retard setting.

The evidence presented by the floor, particularly after comparison with similar works in Rome show it to be a unique example of its kind, and of very great importance to the study of Northern European Medieval architectural decoration, appropriate use of materials and contacts with Rome. The floor is, as in the words of James Peller Malcolm, "The most glorious work in England, venerable through age, costly in its materials and invaluable for its workmanship" Malcolm (1802).

\section{References}

Adams, A. E., MacKenzie, W. S. and Guildford, C., 1991, Atlas of sedimentary rocks under the microscope. Longman Scientific \& Technical. $104 \mathrm{pp}$.

Binski, P., 2002, the Cosmati and romanitas in England: an overview., in: L. Grant \& R. Mortimer (Eds.), Westminster Abbey: The Cosmati Pavements., Courtauld Research Papers No. 3., Ashgate., 116-134.

Carpenter, D., 2002, Westminster Abbey and the Cosmati Pavements in Politics 1258-1269., in: L. Grant \& R. Mortimer (Eds.), Westminster Abbey: The Cosmati Pavements., Courtauld Research Papers No. 3., Ashgate., 37-48.

Deer, W. A., Howie, R. A and Zussman, J., 1992, An introduction to the rock forming minerals - 2nd edition., Longman Scientific \& Technical. 696 pp.

Durnan, N., 2002, The condition and conservation of the Cosmati pavements at Westminster Abbey., in: L. Grant \& R. Mortimer (Eds.), Westminster Abbey: The Cosmati Pavements., Courtauld Research Papers No. 3., Ashgate., 92-99.

Foster, R., 1991, Patterns of Thought: The Hidden Meaning of the Great Pavement of Westminster Abbey., Jonathan Cape, London., 184 pp.

Foster, R., 2002, The context and fabric of the Westminster Abbey Sanctuary pavement., in: L. Grant \& R. Mortimer., Westminster Abbey: The Cosmati Pavements., Courtauld Research Papers no. 3.; Ashgate Publishing Ltd. 49-91.

Freestone, I. C., 1995, Ceramic Petrography. American Journal of Archaeology., 99, 111-115.

Jordan, W. J., 1980, Sir George Gilbert Scott R. A., Surveyor to Westminster Abbey 1849-1878., Architectural History, 23, 60-85 (Appendices 188-190).

Malcolm, James Peller, 1802, Londinium redivivum; or, An Ancient History and Modern Description of London., London.

Pajares-Ayuela, P. (transl. M. Fleming Alvarez), 2001, Cosmatesque Ornament: Flat Polychrome Geometric Patterns in Architecture., W. W. Norton \& Co., New York, London., 320 pp.

St John, D. A., Poole, A. W. \& Sims, I., 1998, Concrete Petrography: a handbook of investigative techniques., Arnold, London., 474 pp.

Tucker, M. E., 1991, Sedimentary petrology - 2nd edition., Blackwell Scientific Publications. 260 pp.

Whitbread, I. K. 1986, The characterisation of argillaceous inclusions in ceramic thin sections. Archaeometry, 28, 79-88.

Whitbread, I. K., 1989, A proposal for the systematic description of thin sections towards the study of ancient ceramic technology. Archaeometry, 31, 127-138. 